family therapy; and by Dr Douglas Haldane on his survey of marriage guidance methods among Scottish colleagues. Dr Heti Davies made a moving plea for more imaginative supportive services for the families of the mentally handicapped, and Dr Hunter Gillies, that elder statesman of Scottish psychiatry, gave an unforgettable exposition of his fifty years in the specialty which seemed, in retrospect, to span the therapeutic advances of centuries. He recalled the bad old days of restraints, bodyguards and pyretotherapy and the changes brought by the successive advent of barbiturates, amphetamines, insulin, ECT, phenothiazines, antidepressants, lithium and benzodiazepines. He put in a plea for modern research enthusiasms to be tempered by biological sophistication and quantitative measurement. All the papers provoked lively discussion. Members wondered particularly why the incidence of schizophrenia seemed (at least in Scotland) to be diminishing, and what should be the attitude of psychiatrists to the innumerable non-medical problems which nowadays came their way and took up their time. It was suggested that there should be research on these themes.

In the middle of all this serious work we had another, unofficial annual dinner, though without speeches. It was an excellent one.
MARGaret LITTLE

\title{
PROFESSOR DESMOND POND
}

Professor Pond has been elected Chairman of the Conference of Medical Royal Colleges and their Faculties in the UK. This is the first time a President of the College has held this position. Although Professor Pond will be retiring from the Presidency of the College in 1981, he will continue to preside over the Conference for a further year.

\section{PAPERS FOR COLLEGE MEETINGS}

The Programmes and Meetings Committee invites members of the College to submit papers on miscellaneous topics for presentation at the Spring Quarterly Meeting, which is to be held in Montrose on 28 and 29 April, 1981; and for the Annual Meeting which will be held from 7 to 9 July 1981 . I would be grateful to receive summaries of the papers members would like to present. The closing date for the Spring Meeting is 20 December 1980, and for the Annual Meeting, 28 February 1981.

RobIN MURRAY
Honorary Secretary
Programmes \& Meetings Committee

Programmes \& Meetings Committee

\section{MAUDSLEY LECTURE 1980}

The Maudsley Lecture 1980 will be delivered by Sir Martin Roth on 'Contemporary Issues in Psychiatric Diagnosis'. Unfortunately, through circumstances beyond our control, it has been necessary to change the date of the
Lecture which will now be delivered at 5.00 p.m. on Thursday, 20th November 1980 at the Institute of Psychiatry.

\section{Erratum}

It is regretted that the name of Dr Ruth Porter was omitted from the list of Members elected to the Fellowship which was published in the Bulletin in July (page 112). 